\title{
Infants and toddlers: how visible are they in the Early Years Learning Framework?
}

\author{
Belinda Davis $^{{ }^{*}}$, Jane Torr ${ }^{2}$ and Sheila Degotardi ${ }^{2}$
}

\author{
${ }^{*}$ Correspondence: \\ belinda.davis@sydney.edu.au \\ ${ }^{1}$ Sydney University, Sydney, \\ Australia \\ Full list of author information \\ is available at the end of the \\ article
}

\begin{abstract}
Australia's first national early childhood curriculum, the Early Years Learning Framework (Department of Education Employment and Workplace Relations [DEEWR], 2009), aims'to extend and enrich children's learning from birth to five years and through the transition to school' (p. 5). The framework sets out some key principles, practices and learning outcomes to guide educators working with children prior to school age. In its introduction, the framework states that the term children should be understood to refer to infants and toddlers as well as older children, unless otherwise stated. This study used a critical discourse approach to analyse the language used to refer specifically to infants and toddlers, rather than the more generic term children. We found 8 instances where the words baby, babies or toddlers are used. In these sentences, infants and toddlers are construed in the language in terms of their observable behaviour, rather than as communicators or thinkers. We then interviewed six educators working with children under 2 years in long day care centres. The educators stated that they faced challenges in interpreting and implementing the framework in their work with infants. The findings suggest that the distinctive developmental trajectories and learning experiences of infants and toddlers are relatively invisible in the national curriculum. The findings indicate that educators working with children under 2 require more specific information about pedagogy and learning experiences for this particular age group, rather than the present situation, where pedagogy and outcomes for all children under 5 years are conflated into a single learning framework.
\end{abstract}

Keywords: Infants, Toddlers, Educators, Early childhood, Early Years Learning Framework (EYLF), Curriculum, Language

\section{Background}

Recent international attention has focused on the importance of the first 3 years of a child's life for their long term academic achievement and general wellbeing (NICHD Early Childcare Research Network (NICHD ECCRN) 2002; Organisation for Economic Co-operation and Development (OECD) 2011; Shonkoff 2010). A key element in Australia's early childhood reform agenda has been the development and implementation of the country's first national early childhood curriculum, the Early Years Learning Framework (Department of Education Employment and Workplace Relations [DEEWR] 2009). All staff in prior to school services in Australia (preschool, long day care and family day care) are required to implement this 47 page curriculum, which provides guidelines for early childhood pedagogy through the specification of five principles, eight aspects of

(C) 2015 Davis et al. This article is distributed under the terms of the Creative Commons Attribution 4.0 International License (http:// creativecommons.org/licenses/by/4.0/), which permits unrestricted use, distribution, and reproduction in any medium, provided you give appropriate credit to the original author(s) and the source, provide a link to the Creative Commons license, and indicate if changes were made. 
practice and five learning outcomes for children. The EYLF therefore potentially influences the learning environments of all children under 5 years of age attending any type of formal childcare setting. It is, as claimed by its authors, 'a document of considerable significance for contemporary early childhood policy and practice' (Sumsion et al. 2009, p. 4).

While the EYLF encompasses guidelines for the teaching and learning of all children aged from birth to five, there have been suggestions that it is focused primarily on children from 3 to 5 years, with less attention being given to pedagogy and learning outcomes for infants and toddlers aged under 2 years (Sumsion et al. 2009). The challenge of 'locating' the teaching and learning of under 2-year-old children in the EYLF was raised by Salamon (2011) who, while advocating that the EYLF has the potential to be applicable to children across the entire prior to school age range, admits that it could be said that the discourse of the document does not easily reflect this' (p. 5). Salamon argued that the onus is on educators and educational leaders to 'find' references to infants and toddlers in the EYLF document and to understand their relevance to children of this age group. This feature of the EYLF may present a challenge to infant educators as they attempt to interpret and implement the curriculum to support the specific developmental trajectories and learning experiences of infants and toddlers, which differ significantly from those of older children. The present study has been designed to explore in detail the language used in the EYLF to refer specifically to infants and toddlers, as opposed to 'children' in general. The study also sought to investigate the views of educators regarding the language of the EYLF as they attempt to interpret and implement it in their work with children under 2 years.

\section{Defining infants, toddlers and children}

A key feature of the EYLF is the language used to refer to children. A definition is provided in a framed section in the introduction: 'Children refers to babies, toddlers and 3-5 year olds, unless otherwise stated' (p. 6). In this respect, the EYLF differs from other early childhood curricula which use more traditional categories to refer to children of different age groups. For example, the New Zealand curriculum, Te Whāriki (Ministry of Education (MOE) 1996), specifically uses the terms 'infant' and 'toddler' to acknowledge and highlight the unique and distinctive developmental needs, characteristics and curriculum requirements of these very young children. Throughout the Te Whäriki curriculum document, the differences between infants, toddlers and older children are made explicit, reflecting the view that infants require education and care which is specialised and not a 'scaled down 3- or 4-year-old programme' (MOE 1996, p. 22). Furthermore, in England, the now superseded Birth to Three Matters (Department for Education and Skills (DfES) 2002) curriculum framework was specifically designed to recognise the distinctive learning and developmental characteristics of children under 3 years of age. This separate focus on children in the first years of life came about partly in response to a perceived need to increase the professional knowledge base and recognition of those working with infants and toddlers (Langston and Abbott 2005). While Birth to Three Matters has been replaced by the more general Early Years Foundation Stage (Department of Education (DOE) 2012), The failure to specifically refer to infants and toddlers was a major critique of respondents to the revised draft of the EYFS in England (Goouch 
and Powell 2013). However, Scottish educational authorities have decided to retain their focus on the youngest age group through their curriculum (Learning and Teaching Scotland 2010) which explicitly recognises the foundational significance of infancy and provides specific curriculum guidance for those working with the youngest children.

Through their structure, content and discourse patterns, England, Scotland and New Zealand have each highlighted the uniqueness of children's development and learning in the first 2 years of their lives. In contrast, the EYLF has not distinguished between pedagogy and outcomes for children under 2 years compared with those for older children (Salamon 2011; Sumsion et al. 2009). One explanation for the decision to avoid referring explicitly to the distinct developmental and learning requirements of infants, toddlers and older children has been offered by the authors of the EYLF: '.. because of its potential to position infants and toddlers as 'other' in ways that focus on their vulnerabilities, not their capabilities' (Sumsion et al. 2009, p. 9). The authors do, however, concede that such omissions 'can convey universalist assumptions' although they maintain that their decision to produce a single framework for all children under 5 years is justified in that it 'assists in countering deficit, naïve, or romanticised views of children and childhood (Sumsion et al. 2009, p. 9).

The assumption underpinning the present study is that the words and structures employed in any text will shape the attitudes, values and behaviours of readers (Luke 2002; Machin and Mayr 2012). The language of the EYLF will, therefore, have an impact on how children are viewed and how educators working with children perceive their role. This position recognises that childhood, as a concept, is subjective, dependent on the context in which it is defined and the social practices, beliefs and values of the culture in which it is embedded (James and James 2008; James and Prout 1997). Langston and Abbott (2005) argue that 'infancy' is a dynamic construct, which is subject to shifts in prominence in response to temporal and contextual demands. If this is the case, then the presence and characteristics of references to infants and toddlers in curriculum documents may have far reaching effects.

\section{Understanding representations of infants and toddlers through critical discourse analysis (CDA)}

In this paper, we have used the theoretical framework offered by critical discourse analysis (CDA) to investigate how infants and toddlers are represented in the EYLF. CDA aims to reveal how the choice of words, the construction of sentences and other features of the language in a text affect readers and express the ideological stance of the author(s) (Fairclough 1989). Through close analysis of the language used in texts, CDA aims to uncover the 'hidden ideologies' that can influence a reader's view of the world and shape his or her relationships with others (Wodak and Meyer 2009).

Fairclough's (1993) ideas stem from viewing language as being both socially constitutive and socially determined. It is an approach to question the taken-for-grantedness of language and enables explorations of how texts represent the world in particular ways according to particular interests (Fairclough 2001). CDA provides opportunities to consider the relationships between discourse and society (how we view and talk about infants), between text and context (what the EYLF says about infants and early childhood environments) and between language and power (how infants are positioned in 
EYLF and society). Through the linguistic choices they make to represent phenomena, speakers and writers unavoidably shape the attitudes of their audience towards the information being conveyed (Fairclough 2003). The ideological implications derive from the fact that when we name an entity, we use language to presuppose its existence. For example, if a text refers to a 'screaming, unruly child', then it is presupposing that such an individual exists, and that screaming and unruliness are part of the 'package' that is that child. By providing the reader or listener with additional details about the referent (such as 'child') and the nature of the processes in which the referent engages, the author of a text has the power to foreground or suppress ideas, which, in the context of education, can influence professional identities and social practices (Cannella 1997; Fairclough 2001; van Dijk 2001).

Critical discourse analysis involves the analysis of texts. Fairclough highlights the importance of using systemic functional linguistics (Halliday 1994) as the basis for this textual analysis. Texts may constitute written, spoken or multi-modal forms and these are analysed according to specific linguistic and semiotic elements (Fairclough 2003). Nouns do not exist in isolation in the construction of meaning. Nouns function in language to represent participants who are engaged in 'goings-on' of some kind (Halliday 1994). Attitudes are shaped through the choice of verbs in which a named entity is said to engage. For example, if an educator asks a child 'what do you think?' the child is being constructed linguistically as one capable of engaging in mental processes. Hence in this study we have investigated both the manner in which infants are represented through naming (nominal groups) and the activities in which they are said to engage (verbal groups). In English, verbs can be categorised according to the types of 'goings-on' they represent. Halliday (1994) identified 6 categories of verb. Material verbs refer to tangible, observable happenings in which an individual 'does' something that has a material result or consequence (e.g., providing, jumping). Material verbs often denote goal directed actions which have an effect on another entity (Machin and Mayr 2012). Mental verbs refer to inner states of consciousness, which include cognitions (e.g., thinking, knowing), affections (feeling, liking, wanting) and perceptions (seeing, hearing), which must be inferred rather than observed. Relational verbs are concerned with classifying phenomena according to their attributes or identities (e.g., children are curious, Susan is the director). Behavioural verbs refer to the behavioural consequences of physiological or psychological states and represent relatively unintentional, observable responses to an inner state of some kind (e.g., yawn, cough, smile). Verbal processes refer to symbolic communication (e.g., saying, explaining, describing). Finally, existential verbs simply refer to the fact that an entity exists (There is the house).

\section{Aims of this study}

This study aims to:

1. Analyse how infants and toddlers are referred to in the EYLF

2. Determine the views of infant educators regarding the manner in which infants and toddlers are referred to in the EYLF and the consequences for their educational practice. 


\section{Methodology}

\section{Data collection and analysis}

The data analysed in this research were generated from two sources. To address research aim 1, we used samples of the written text of the EYLF as our corpus for analysis. To address research aim 2, the first author interviewed 6 early childhood teachers currently working in settings catering for children aged from 6 weeks to 2 years.

We describe our methods for the data generation and analysis from each source below.

\section{The language used in the EYLF}

A key concept informing document analysis as a form of discourse involves examining the formal properties of a text, including the vocabulary choices and the grammatical features of the text (Fairclough 2003). The EYLF was, therefore, considered a data source and in order to locate all incidences in which infants or toddlers are explicitly referred to within the EYLF, the complete EYLF document was uploaded into QSR NVivo Version 10. This software programme provides electronic coding and synthesising of text, and enables comparisons to be made between different features of qualitative data. Queries were generated to locate all occurrences of the nouns baby, infant, toddler, children and learners. These queries were expanded to include derivatives of the nouns such as babies, infants and toddlers. A frequency count of these key terms was then calculated. A corpus comprising all sentences containing these key terms was then generated in preparation for detailed analysis. Drawing on Fairclough (2003), and underpinned by systemic functional linguistic theory (Halliday 1994), these sentences were then divided into clauses and analysed in terms of the participants (typically realised as nouns or modifiers) and the processes in which the participants were said to engage (typically realised as verbs).

\section{Interviews with educators}

Six early childhood educators participated in an interview for this study. The participants were all university qualified early childhood educators, who worked full time in nurseries which catered for children aged from 6 weeks to 2 years, and who were the room leaders in their infant room. A further requirement was that they had been working with the EYLF for 2 years; thus, they had some experience with the EYLF and were responsible for its implementation in their daily practice.

In Australia, it is uncommon for university qualified educators to work with children under 2 years of age, so convenience sampling (Richards and Morse 2013) was used to locate educators from not-for-profit long day care centres in the Sydney metropolitan district. For this study, it was important for the participants to have university early childhood qualifications, as such staff have been shown to draw on theoretical knowledge, to engage in positive, sensitive care-giving and to provide planned child-centred learning experiences (Howes et al. 1998). These educators then were invited to participate in the research. All were female, aged over 18 years and proficient in English. Following approval from university and centre ethics committees, the first author then interviewed each educator in her workplace. Each interview was digitally audio-recorded to enable full verbatim transcription for analysis. The interviews varied in length from 14 to $33 \mathrm{~min}$. 
The six early childhood educator participants represent what Yin (2014) describes as 'common cases'; that is, they represent common trajectories. The interview protocol was the same for each participant, with open ended questions and plentiful opportunities for additional comments and discussion. Sample questions included: Can you please tell me about the curriculum for infants and toddlers in your room? How does this fit with the philosophy and vision of the centre and link to the EYLF? Do you see the EYLF as providing a language to talk about your work as an educator? Are there any parts of the EYLF that you are having difficulty relating to infants and toddlers? Are there any parts of your practice that you do not see as having been included in the EYLF?

The transcribed interviews were analysed using an interpretive, thematic analysis approach (Braun and Clarke 2006; Maykut and Morehouse 1994). The data were read and margin notes were made to identify key points related to participants' perspectives about the EYLF curriculum document to inform their pedagogy and practice as infant educators. Once margin notes were complete, these notes were compared and contrasted with each other in order to develop and then articulate key themes that emerged from the data (Strauss and Corbin 1998). These themes were further informed by examining the educators responses with reference to the statements about infants and toddlers contained within the EYLF. The emerging themes were collaboratively discussed and defined through triangulation of the data with each author to address internal validity (Andrade 2009; Johnson and Burke 2012; Miles and Huberman 1994).

\section{Results}

\section{The linguistic representation of infants and toddlers in the EYLF}

As the point of departure for this analysis, we calculated the frequency with which the lexical items babies and toddlers appear in the EYLF, relative to the total occurrence of the superordinate terms children and learners, as the presence or omission of naming of entities is an important discourse variable.

Overall, the majority of references to individuals from birth to 5 years in the EYLF used the generic, superordinate terms children $(\mathrm{n}=518)$ and learners $(\mathrm{n}=16)$. Such lexical items are non-specific in terms of the age or developmental characteristics of the referent. In general parlance, the term child could apply to any person under the age of 18 years, while the term learner does not imply any particular age group at all.

The lexical items babies, infants and toddlers, which refer explicitly to the particular characteristics and developmental trajectories of children under 2 years of age, occur relatively infrequently. There were five sentences containing the word babies, one sentence containing the word toddlers, and two sentences referring to both babies and toddlers. The term infant does not occur in the EYLF. In other words, infants and toddlers are rarely represented as a distinct category in the language of the EYLF. As intended by the authors, they are mostly subsumed under the more general category of children.

We therefore now look more closely at the eight sentences where infants and toddlers are specifically named, in order to analyse how they are construed within the grammar in terms of the activities in which they are said to engage and their role relative to educators and other children. These eight sentences are listed below, with the finite and non-finite verbal groups, and nominalisations, delineated in bold. Clause boundaries are marked with/. Please note that the sentence construction in the EYLF is frequently 
complex and grammatically metaphorical, requiring a degree of interpretation on the part of the analyst (Halliday and Matthiessen 2004).

1. Research has shown/that babies are both vulnerable and competent (DEEWR 2009, p. 12)

2. Babies' first attachments within their families and within other trusting relationships provide them with a secure base for exploration and learning (DEEWR 2009, p.12)

3. Educators interact with babies and children/to build attachment (DEEWR 2009, p.15)

4. Educators promote this learning,/for example, when they initiate one-to-one interactions with children, particularly babies and toddlers, during daily routines (DEEWR 2009, p. 24)

5. Babies participate/through smiling, crying, imitating, and making sounds/to show their level of interest/in relating to or participating with others (DEEWR 2009, p.25)

6. Toddlers participate and connect with other toddlers through such gestures/as offering their teddy to a distressed child/or welcoming a new child enthusiastically (DEEWR 2009, p.15)

7. Educators promote this learning,/for example, when they provide babies and toddlers with resources that offer challenge, intrigue and surprise,/support their investigations/and share their enjoyment (DEEWR 2009, p.34)

8. Educators promote this learning,/for example, when they engage in enjoyable interactions with babies/as they make and play with sounds (DEEWR 2009, p.40)

We now look more closely at the nature of the processes in which infants and toddlers are construed as engaging, and the role they themselves play in such processes. In other words, are they positioned as the subjects and doers of the process, or are they the recipient of the processes of others? Halliday's systemic functional linguistic theory (1994), built upon by Fairclough (2003), offers a useful paradigm for exploring this feature of the semantic patterning in texts. Table 1 sets out the processes in which the participants (educators, infants and toddlers) are depicted as engaging.

It can be seen from Table 2 that, when babies and toddlers are specifically named in the EYLF as subjects of the clause, they are largely construed as 'behaviours' or 'doers' in the grammar. Neither infants nor toddlers are construed as engaging in mental or verbal processes such as communicating, talking, thinking, and feeling. The focus is, therefore, on their external behaviour, rather than on aspects of verbal or psychological agency. The use of nominalisations, such as crying, exploration, smiling and learning, has the effect of distancing the action from the actor, and thus contributes to the idea that behaviours happen as a result of circumstances as opposed to intentional action (Machin and Mayr 2012). This further de-emphasises agency and results in a relatively non-specific portrayal of behaviours. Overall, it is as if the infant is being construed in the text as one who is unable to communicate directly or engage in mental processes, as his or her inner state must be inferred from the outwardly visible behaviours he or she exhibits.

Educators, on the other hand, are construed in the grammar as engaging in material processes-interacting, building, promoting, supporting, and so on, with infants frequently depicted as responding to stimuli provided by the educators. In five of the eight 
Table 1 Educators' qualifications and experience

\begin{tabular}{|c|c|c|}
\hline Pseudonym & Qualification & Experience \\
\hline Dora & $\begin{array}{l}\text { Bachelor of Teaching } \\
\text { (Early Childhood) }\end{array}$ & $\begin{array}{l}\text { Dora had worked in early childhood centres for } 7 \text { years. } \\
\text { She had been the team leader in the infants room for } \\
\text { the past } 2 \text { years }\end{array}$ \\
\hline Kate & $\begin{array}{l}\text { Bachelor of Teaching } \\
\text { (Early Childhood) }\end{array}$ & $\begin{array}{l}\text { Kate had worked for } 3 \text { years at the same centre and was } \\
\text { the room leader in the infants room }\end{array}$ \\
\hline Tinny & $\begin{array}{l}\text { Bachelor of Education } \\
\text { (Early Childhood) }\end{array}$ & $\begin{array}{l}\text { Tinny had worked in long day care for } 5 \text { years and in } \\
\text { her current role for } 2 \text { years as the team leader in the } \\
\text { infants room }\end{array}$ \\
\hline Sarah & $\begin{array}{l}\text { Bachelor of Teaching } \\
\text { (Early Childhood) }\end{array}$ & $\begin{array}{l}\text { Sarah had worked in early childhood centres for } 3 \text { years } \\
\text { at the current centre for } 2 \text { years as the team leader in } \\
\text { the infants room }\end{array}$ \\
\hline Beth & $\begin{array}{l}\text { Bachelor of Education } \\
\text { (Early Childhood) }\end{array}$ & $\begin{array}{l}\text { Beth had worked for } 20 \text { years in a range of centres but } \\
\text { had been at the current centre for } 5 \text { years working as } \\
\text { the team leader in the infants room }\end{array}$ \\
\hline Ellie & $\begin{array}{l}\text { Bachelor of Education } \\
\text { (Early Childhood) }\end{array}$ & $\begin{array}{l}\text { Ellie had worked at the current centre for } 4 \text { years work- } \\
\text { ing in her current role as the team leader in the infants } \\
\text { room }\end{array}$ \\
\hline
\end{tabular}

Table 2 Processes and process types related to each verb subject

\begin{tabular}{lll}
\hline $\begin{array}{l}\text { Subject of the verb } \\
\text { and "doer" of the action }\end{array}$ & Process in which subject is engaged & Process type \\
\hline Babies & Are [vulnerable and competent] & \\
& $\begin{array}{l}\text { Participate [through smiling, crying, imitating, and making } \\
\text { sounds] } \\
\text { Show [interest in relating to or participating] }\end{array}$ & Relational \\
& Make [sounds] & Behavioural \\
& Play [with sounds] & Behavioural \\
& Relating [to others] & Behavioural \\
& Participating [with others] & Behavioural \\
& Participate & Behavioural \\
& Connect [with other toddlers] & Behavioural \\
Toddlers & Offering [their teddy] & Behavioural \\
& Welcoming [a new child] & Behavioural \\
Educators & Interact [with babies and children to] & Material \\
& Build [attachment] & Behavioural \\
& Promote [this learning] & Material/verbal \\
& Initiate [one-to-one interactions] & Material \\
Research & Provide [resources] & Material \\
Resources & Support [their investigations] & Material \\
\hline & Share [their enjoyment] & Material \\
Engage in [enjoyable interactions & Has shown & Material \\
& Provide & Material \\
& Offer, support & Material \\
& & Material \\
& Material \\
& Material \\
\hline
\end{tabular}

sentences in the EYLF which contain the lexical items babies or toddlers, it is the educator who is positioned in the language as the 'doer' of the actions. While this highlights the important role of the educator, it also serves to imply that when babies and toddlers are specifically referred to, they are primarily represented as the recipients of educators' 
actions, rather than as actors in their own terms. With the exception of the non-specific reference to 'interact' (statement 3), which could potentially be construed as involving verbal processes, there is no reference to educators talking to infants, nor to infants communicating or toddlers talking to educators.

\section{Educators' views about the language used in the EYLF to represent infants and toddlers}

In this section, we report on those sections of the interview data in which educators referred specifically to the language used in the EYLF to refer to children, infants and toddlers. Please note that the interviews traversed a wide range of topics and in this section we have focused only on those aspects relevant to our research aims. The following themes emerged from the data.

\section{Inclusion and exclusion}

The educators all expressed difficulty in locating infant-toddler pedagogy and learning within the EYLF document.

It's a shame that they have not used the term 'infant,' 'babies' and 'toddlers' a lot in the EYLF. It's mainly mentioned about the children, the children not as babies, toddlers and infants (Sarah)

Educator Sarah suggested that this could be the result of an oversight on the part of the authors of the EYLF. Other educators expressed their disappointment at what appeared to be a missed opportunity for the EYLF to foreground the first years of life. There was a sense that infants and toddlers, and their educators, were excluded from the curriculum:

I feel that in using 'infants', 'babies' and 'toddlers', there may actually be some attainable goals through the EYLF which are not there currently (Dora)

Having those, the infants and toddlers in there, might actually get people to re-shift, and think 'Oh yes, this can be used for infants, it's intended to be used with them' (Ellie)

Statements such as these implied that the educators felt that infants and toddlers lacked visibility in the EYLF, which potentially could see them as being excluded from the learning outcomes and principles that were promoted within the document. Issues of inclusion and exclusion were also raised by Beth who suggested that the intention not to refer explicitly to infants and toddlers presented a difficulty in her work which needs to be rectified:

They should be included, considering I predominantly work with zero to two's and they fit under the term infant, babies and toddlers. Also, it's my age where I really prefer to work so for me, referring to the EYLF becomes a way I can accommodate that into our program because we run a baby and toddler program here (Beth)

This is an important point because it provides a direct contrast to the original justification for using the word children as a general term for all children under 5 years; that is, in order not designate infants and toddlers into a separate category as 'other'. While the motivation behind this decision may have been to emphasise inclusion rather than 
exclusion, it would appear that, for these educators, it has had the unintended consequence of generating a feeling of exclusion. Tinny reflected this view when she expressed her a difficulty in relating her work to the EYLF, explaining that her role as a teacher of infants and toddlers also appeared to also be excluded:

Because I work with this age group, I feel sometimes that certain things that you read in the EYLF you feel a little bit excluded because it doesn't, it's generally saying about children but also not establishing or acknowledging the fact that the age group for infants and toddlers are a little bit different (Tinny)

\section{Discussion and implications}

This study was designed to analyse the language used in the EYLF to refer to children under 2 years of age from two perspectives; the manner in which infants and toddlers are represented linguistically in the document itself, and the manner in which educators working with infants in long day care centres reflect upon and respond to that representation. The fact that infants and toddlers are rarely specifically named in the EYLF, being subsumed under the more general term children, appears to render infancy relatively invisible in the document. In any text, expressions which are used frequently are foregrounded through repetition, suggesting to the reader that the meanings they represent have greater relevance and importance than other, less frequently occurring terms and concepts. Thus, the repetition of particular terms and expressions shape the reader's response and understanding of what is most significant in a text (Eggins 2004).

The decision by the authors of the EYLF to refer to a single category children, and in so doing to propose a universal set of pedagogical principles, practices and outcomes applicable to all children from 6 weeks to 5 years of age, appears to have had some unintended consequences. Several of the outcomes in the EYLF appear to be targeted at children aged from 3 to 5 years, for example "children begin to use images and approximations of letters and words to convey meaning" and "children use language and engage in play to imagine and create roles, scripts and ideas" (DEEWR 2009, p. 42). Such outcomes are clearly not relevant to preverbal children. Likewise, pedagogical practices for educators suggesting they "ask and answer questions during the reading and discussion of books and other texts" (DEEWR 2009, p. 42) would make sense only if one is referring to a child aged over 18 months at the bare minimum. The fact that the EYLF appears to focus on older children has proven to be a challenge for infant educators who are attempting to interpret and implement the document in ways that are responsive to the children in their care.

Another potentially serious consequence of the invisibility of infants and toddlers in the EYLF is the unintended message that the education and care of children under 2 years is not as important as that of older children. A separate curriculum for children under 2 years would serve to highlight to the specialist nature of the work being undertaken by infant educators. The teachers we interviewed held strong views on the importance of explicitly naming the children they care for and educate, and the lack of visibility was collectively identified as a concern. These university qualified early childhood teachers expressed regret at this lack of visibility, feeling that an opportunity was missed to include infants and toddlers in this important, guiding document, as they expressed 
difficulties in establishing clear paths of relevance to many aspects of the EYLF, in particular the language and cognitive outcomes. Overall, the EYLF statements and the teachers' responses to them seemed to reinforce a relatively limited view of infant-toddler teaching and learning. Our findings support recent calls for a reconceptualization of infant-toddler pedagogy to include a clearer recognition of infant-toddler capabilities and contributions to their own learning, as well as a stronger knowledge base for educators to support all areas of learning and development (Degotardi 2009; Harrison and Sumsion 2014; Sumsion and Harrison 2014).

The lack of reference to infants and toddlers in the EYLF was experienced by some educators as indicative of a general lack of status and recognition of their specialised role as infant educators. In Australia and the UK, concerns have been raised about the perceived professional status and morale of those working with infants and toddlers (Degotardi 2012; Goouch and Powell 2013). Of particular relevance are research findings that infant-toddler educators often feel marginalised from others working with older children (Clark and Baylis 2012). While our findings are clearly exploratory, reports from some of these university qualified educators that they found it difficult to locate their own professional practice within the EYLF are of concern. With international research and professional literature demonstrating the complexity of infant-toddler learning and teaching (Degotardi 2014; Harrison and Sumsion 2014) as well as the importance of a strong professional identity for effective pedagogy (Page et al. 2013; Powell and Goouch 2012), our findings suggest that the language of curriculum documents could potentially have negative impacts on the programmes that they aim to support.

\section{Limitations}

There are some limitations in this research which need to be acknowledged. The inclusion of only six centres from relatively high socio-economic suburbs in the Sydney metropolitan area limits the extent to which the present findings can be generalised to both national and international contexts. The participants represented a small sample and readily provided consent which may imply that they were confident in their practice. These aspects suggest that the participants are unlikely to be representative of other early childhood educators currently working in Australian long day care centres with children under 2 years of age. A further limitation in using SFL may be seen as it being limited to linguistic analysis. However, the use of qualitative interviews permitted the authors to discuss the qualitative coding of the interview responses and the EYLF analysis to triangulate the data using exact quotations from the EYLF and the educators themselves to address this aspect of validity.

\section{Conclusion}

Sumsion et al. (2009) has invited the early childhood field to engage in 'critical analysis and debate about directions for its future development' (p. 11). As the arena of infanttoddler research remains under-represented in the early childhood field (Berthelsen, 2010), further research is necessary to provide much needed information about how educators could make infants and toddlers 'visible' in the EYLF. As Goouch and Powell (2013) argue 'what is not said in a policy may be just as important as or even more important and illuminating than what is included' (p. 114) and the silence in relation to 
infants and toddlers in the EYLF is an important finding. While justifying their omission of the terms 'infants' and 'toddlers' the authors concede that this could be a 'point of tension' that educators face when using the document (Sumsion et al. 2009). This research has confirmed that such omissions were indeed a 'point of tension' for their reported interpretation and practice. This silence may relegate infants and toddlers to a place of irrelevance and this has implications for practice. We argue that Australia should follow other countries such as England, Scotland and New Zealand and provide a curriculum document that is relevant for infants, toddlers and their teachers.

Future studies may examine early childhood curricula in other countries to determine how infants and toddlers are represented and the implications of this for early childhood practice. There is emerging evidence in this regard from the UK (Brooker 2010; Powell and Goouch 2012; Taggart 2011) and the US (Shin 2014), so it would be beneficial to compare conceptualisations of infant-toddler pedagogy given that many countries now have early childhood curricula and have begun examining educators' perspectives to varying degrees.

A further limitation of using CDA and following Halliday's grammar of semantic meaning by examining individual sentences and their linguistic features may be seen to involve researcher bias and impressionistic commentary. Methods triangulation and data triangulation were used and are important aspects for improving internal validity. Data were collected from the EYLF and the interviews. This approach complements data triangulation, as information from more than one source was able to be considered so as to determine links and relationships between discourses and practice. The combination of information provides a more holistic understanding rather than relying on one data source only. We have provided triangulation of the data using exact quotations from the EYLF and the teachers themselves to address this aspect of validity.

\section{Authors' contributions}

BD conceptualised, conducted and analysed the research. JT applied SFL for linguistic analysis. SD helped design, draft and analyse the research. All authors contributed to the design, interpretation and revisions of the research article. All authors have agreed to the final version sent out for review. I have undertaken the responsibility to keep the co-authors informed of our progress through the editorial review process, the contents of the reviews, and any revisions made. I understand that, if accepted for publication, a certification of authorship form will be required that all co-authors will sign. All authors read and approved the final manuscript.

\section{Author details}

${ }^{1}$ Sydney University, Sydney, Australia. ${ }^{2}$ Macquarie University, Sydney, Australia.

\section{Acknowledgements}

Acknowledgements must go to the infant educators who contributed their valuable time and knowledge to enable this research to be conducted. Also, to the centre, staff and children who kindly agreed to be part of this research.

\section{Compliance with ethical guidelines}

\section{Competing interests}

We have no competing interests, affiliations, financial or non-financial with anyone associated with this research. This research was conducted without any funding. We have no competing interests in the interpretation or presentation of the data. There were no personal, financial or non-financial interests in the past 3 years from any organisation. The authors and I would, therefore, like the following statement to appear at the end of the article: 'The author(s) declare that they have no competing interests'.

Received: 20 March 2015 Accepted: 24 August 2015

Published online: 28 September 2015

\section{References}

Andrade, A. D. (2009). Interpretive research aiming at theory building: adopting and adapting the case study design. The Qualitative Report, 14(1), 42-60. 
Berthelsen, D. (2010). Introduction. International Journal of Early Childhood, 42, 81-86. doi:10.1007/s13158-010-0020-8. Braun, V., \& Clarke, V. (2006). Using thematic analysis in psychology. Qualitative Research in Psychology, 3(2), 77-101. doi:10.1191/1478088706qp063oa.

Brooker, L. (2010). Constructing the triangle of care: Power and professionalism in practitioner/parent relationships. British Journal of Educational Studies, 58(2), 181-196. doi:10.1080/00071001003752203.

Cannella, G. S. (1997). Deconstructing early childhood education: social justice and revolution. New York, NY: Peter Lang Publishing.

Clark, R. M., \& Baylis, S. (2012). 'Wasted down there': policy and practice with under threes. Early Years: An international Journal of Research and Development, 32(2), 229-242. doi:10.1080/09575146.2011.652939.

Department for Education and Skills (DfES). (2002). Birth to three matters. Nottingham: DfES Publications.

Department of Education (DOE). (2012). Statutory framework for the early years Foundation Stage: setting the standards for learning, development and care for children from birth to five. London: Department of Education Retrieved from http://webarchive.nationalarchives.gov.uk/20081230004520/, http://www.standards.dfes.gov.uk/eyfs/resources/ downloads/statutory-framework-update.pdf.

Department of Education Employment and Workplace Relations [DEEWR]. (2009). Belonging, being and becoming: the early years learning framework for Australia. Canberra: Department of Education, Employment and Workplace Relations Retrieved from http://docs.education.gov.au/system/files/doc/other/belonging_being_and_becoming_the_early_years_learning_framework_for_australia.pdf.

Degotardi, S., \& Pearson, E. (2009). Relationship theory in the nursery: attachment and beyond. Contemporary Issues in Early Childhood, 10, 144-155. doi:10.2304/ciec.2009.10.2.144.

Degotardi, S., \& Sweller, N. (2012). Mind-mindedness in infant child-care: associations with early childhood practitioner sensitivity and stimulation. Early Childhood Research Quarterly, 27, 253-265. doi:10.1016/j.ecresq.2011.09.002.

Degotardi, S., \& Pearson, E. (2014). The relationship world of infants and toddlers: Multiple perspectives from early years theory and practice. Open University Press: Maidenhead, UK.

Eggins, S. (2004). Introduction to systemic functional linguistics (2nd ed.). New York: Continuum.

Fairclough, N. (1989). Lanquage and power. London: Longman.

Fairclough, N. (1993). Critical discourse analysis and the marketization of public discourse: the universities. Discourse and Society, 4(2), 133-168. doi:10.1177/0957926593004002002.

Fairclough, N. (2001). The discourse of New Labour: critical discourse analysis. In M. Wetherell, S. Taylor, \& S. Yates (Eds.) Discourse as data: a guide for analysis (pp. 229-266). London: Sage.

Fairclough, N. (2003). Analysing discourse: textual analysis for social research. London: Routledge.

Goouch, K., \& Powell, S. (2013). The baby room: principals, policy and practice. Maidenhead: Open University Press.

Halliday, M. A. K. (1994). An introduction to functional grammar (2nd ed.). London: Edward Arnold.

Halliday, M. A. K., \& Matthiessen, C. (2004). An introduction to functional grammar (3rd ed.). London: Arnold.

Harrison, L., \& Sumsion, J. (Eds.). (2014). Lived spaces of infant-toddler education and care: exploring diverse perspective on theory, research, practice and policy. New York: Springer.

Howes, C., Hamilton, C. E., \& Philipsen, L. C. (1998). Stability and continuity of child care-giver and child peer relationships. Child Development, 69(2), 418-426. doi:10.1111/j.1467-8624.1998.tb06199.x.

James, A., \& James, A. (2008). Key concepts in childhood studies. London: Sage.

James, A., \& Prout, A. (1997). Constructing and reconstructing childhood. Basingstoke: Falmer Press.

Johnson, B., \& Burke, J. (2012). Educational research: quantitative, qualitative, and mixed approaches. Thousand Oaks: Sage Publications.

Langston, A., \& Abbott, L. (2005). Quality matters. In L. Abbott \& A. Langston (Eds.), Birth to three matters (pp. 68-78). Maidenhead: Open University Press.

Learning and Teaching Scotland. (2010). Pre-birth to three: Positive outcomes for Scotland's children and families. Glasgow: Scottish Government.

Luke, A. (2002). Beyond science and ideology critique: Development in critical discourse analysis. Annual Review of Applied Linguistics, 22, 96-110. doi:10.1017/S0267190502000053.

Machin, D., \& Mayr, A. (2012). How to do critical discourse analysis: a multimodal introduction. Los Angeles: Sage.

Maykut, P., \& Morehouse, R. (1994). Beginning qualitative research: a philosophic and practical guide. Washington DC: Falmer Press.

Miles, M. B., \& Huberman, A. M. (1994). Qualitative data analysis: an expanded sourcebook. Los Angeles: Sage.

Ministry of Education (MOE). (1996). Te Whàriki: He Whàriki Màtauranga mò ngà Mokopuna o Aotearoa. Wellington: New Zealand Ministry of Education Retrieved from http://www.educate.ece.govt.nz/ /media/Educate/Files/Reference\%20Downloads/whariki.pdf.

NICHD Early Childcare Research Network (NICHD ECCRN). (2002). Child-care structure $\rightarrow$ process $\rightarrow$ outcome: Direct and indirect effects of child-care quality on young children's development. Psychological Science, 13(3), 199-206. doi:10.1111/1467-9280.00438.

Organisation for Economic Co-operation and Development (OECD). (2011). Starting strong III—a quality toolbox for early childhood education and care. Retrieved from http://www.oecd.org/edu/school/startingstrongiiiaqualitytoolboxforecec.htm.

Page, J., Clare, A., \& Nutbrown, C. (2013). Working with babies and children from birth to three. London: Sage Publications.

Powell, S., \& Goouch, K. (2012). Whose hand rocks the cradle? Parallel discourses in the baby room. Early Years: An international Journal of Research and Development, 32(2), 113-127. doi:10.1080/09575146.2012.687865.

Richards, L., \& Morse, J. M. (2013). Readme first for a user's guide to qualitative methods (3rd ed.). Los Angeles: Sage.

Salamon, A. (2011). How the Early Years Learning Framework can help shift pervasive beliefs of the social and emotional capabilities of infants and toddlers. Contemporary Issues in Early Childhood, 12(1), 4-10. doi:10.2304/ciec.2011.12.1.4.

Shin, M. (2014). Enacting caring pedagogy in the infant classroom. Early Child Development and Care, doi:10.1080/030044 30.2014.940929.

Shonkoff, J. P. (2010). Building a new biodevelopmental framework to guide the future of early childhood policy. Child Development, 81(1), 357-367. doi:10.1111/j.1467-8624.2009.01399.x. 
Strauss, A., \& Corbin, J. (1998). Basics of qualitative research: techniques and procedures for developing grounded theory. London: Sage.

Sumsion, J., Barnes, S., Cheeseman, S., Harrison, L., Kennedy, A., \& Stonehouse, A. (2009). Insider perspectives on developing Belonging, Being and Becoming: the Early Years Learning Framework for Australia. Australasian Journal of Early Childhood, 34(4), 4-13. http://www.earlychildhoodaustralia.org.au/wp-content/uploads/2014/06/AJEC0904.pdf.

Sumsion, J., \& Harrison, L. (2014). Introduction: Exploring lived spaces of infant-toddler education and care. In L. Harrison \& J. Sumsion (Eds.), lived spaces of infant-toddler education and care (pp. 1-16). New York: Springer.

Taggart, G. (2011). Don't we care?: The ethics and emotional labour of early years professionalism. Early Years, 31(1), 85-95. doi:10.1080/09575146.2010.536948.

van Dijk, T. (2001). Multidisciplinary CDA: a plea for diversity. In R. Wodak \& M. Meyer (Eds.), Methods of critical discourse analysis (pp. 95-119). London: Sage.

Wodak, R., \& Meyer, M. (2009). Critical discourse analysis: history, agenda, theory and methodology. In R. Wodak \& M. Meyer (Eds.), Methods for critical discourse analysis (2nd ed., pp. 1-33). London: Sage.

Yin, R. K. (2014). Case study research: design and methods. Los Angeles: SAGE.

\section{Submit your manuscript to a SpringerOpen ${ }^{\circ}$} journal and benefit from:

- Convenient online submission

- Rigorous peer review

- Immediate publication on acceptance

- Open access: articles freely available online

- High visibility within the field

- Retaining the copyright to your article

Submit your next manuscript at $\mathbf{s p r i n g e r o p e n . c o m ~}$ 